№ 29 (2020) стор. 79-84

The National Academy of Fine Arts and Architecture

Ukrainian Academy of Fine Art. Research and Methodology Papers

ISSN 2411-3034

Website: http://naoma-science.kiev.ua/

УДК 75.042:[598.2+75.043]]:615.85

ORCHID iD 0000-0002-7226-5329

DOI: https://doi.org/10.33838/naoma.29.2020.79-84

\author{
Dr. Biyun Zhang (张碧云) \\ Zhejiang University of Technology, Hangzhou, Zhejiang, 310014 \\ zhangbiyun2013@163.com
}

\title{
RESEARCH ON FLOWER-AND-BIRD PAINTING IN ART THERAPY OF DEPRESSION
}

\begin{abstract}
Flower-and-bird painting (FABP) is one of the traditional branches of Chinese painting. Traditional Chinese FABP reflects Chinese national aesthetic ap-preciation of natural creatures. It can express the author's thoughts and feelings, re-flect the spirit of time and social life. In view of the low efficiency and unobvious results of the current language-psychological treatment of depression, this paper stu-dies the historical development and artistic characteristics of FABP, then considers the emotional disorders of patients with depression to analyze the ways and effects of using FABP in depression treatment and curing, to provide a better option of art therapy for the increasing number of depression patients in China and worldwide.
\end{abstract}

Keywords: flower-and-bird painting; historical development, artistic features, depression, art therapy.

\section{ДОСЛІДЖЕННЯ ЖИВОПИСУ ЖАНРУ «КВІТИ І ПТАХИ» В АРТ-ТЕРАПІЇ ДЕПРЕСІЇ}

\section{Біюнь Джан}

Анотація. Китайський традиційний живопис жанру «Квіти і птахи» (КіП) - один з традиційних живописних жанрів китайського образотворчого мистецтва. Традиційний китайський живопис КіП відображає естетичну оцінку природи за китайською традицією. Він може висловлювати думки та почуття автора, відображати дух часу та суспільного життя. 3 огляду на низьку ефективність та неочевидні результати сучасного лінгво-психологічного лікування депресії, ия робота вивчає історичний розвиток та художні характеристики FАBP, розглядає емоційні розлади пацієнтів з депресією для аналізу шляхів та наслідків використання КіП у боротьбі з депресією, з метою забезпечення кращих результатів арт-терапії для зростаючої кількості хворих на депресію в Китаї та в усьому світі. В сучасних умовах швидкого темпу життя, надлишкової урбанізації та зростаючого інформаційного тиску на особистість ментальні розлади стають проблемою більшої частини населення. Водночас чимало людей з розладами не усвідомлюють ні наявної проблеми, ні шляхів ї̈ можлливого вирішення. Тому актуальнішим стає питання добровільної участі пацієнтів у терапевтичних практиках, які мають бути цікавими та ефективними. Саме тут арт-терапія із застосуванням традиційних жанрів виявляється максимально елективною. Відповідність КіП усім цим вимогам розглядається у статті. Особливий акцент зроблений на ефективності і дієвості досліджуваної методики для китайських пацієнтів з відповідним культурним підгрунтям. Детально розглянуто й продемонстровано доцільність використання КіП як арт-терапії під час лікування хворих на депресію. Показано, що поряд з медикаментозним лікуванням арт-терапія КіП, що замінює лінгво-психологічну терапію, є найкращим способом лікування депресій. Зроблено висновок, що хоч КіП $і$ застосовується у психотерапії, цей метод ще потребує подальшого розвитку й аналізу унікальних особливостей, що можуть збільшити його практичне значення. Введено в обіг вагомий пласт джерел китайських авторів з окресленої проблематики. Отримані в ході цього дослідження результати можуть бути використані для глибшого 
вивчення теми іншими авторами для розробки терапевтичної та педагогічної практик. Показана перевага розглянутого методу над іншими методами арт-терапї, а саме над лінгво-психологічними методами, які сьогодні застосовують набагато інтенсивніше і ширше ніж арт-терапія.

Ключові слова: китайський традиційний живопис жанру Квіти і Птахи, іс-торичний розвиток, художні особливості, депресія, арт-терапія.

Formulation of the problem. Painting therapy focuses on using painting as a method and means to treat patients' physical and psychological diseases and achieve the function of promoting rehabilitation with different expressive techniques to achieve the communication with the patient. Learning painting is one of the therapeutic methods most acceptable by the patients, their family members and friends, as it can act as a simple activity like participating in an interest class on weekends. Still there is a room for further study of ways to voluntarily involve patients and their recognition of the existing disorder, i.e. finding a way to comfortably solve the problem. According to the research of the author, FABP is one of the best art therapies among traditional Chinese paintings. The reasons for choosing this painting will be discussed in details.

Relevance of research. In modern conditions of constant growth of the pace of life, excessive urbanization and increasing information pressure on every individual, mental disorders are becoming a problem for more and more people. At the same time, the majority of the affected population is not aware of the existing problem or ways to solve it. Therefore, the issue of voluntary participation of patients in thera-peutic practices, which should be interesting and effective at the same time, is becoming increasingly important. It is here that art therapy with the use of traditional painting genres turns out to be most effective.

Connection of the author's work with important scientific and practical tasks. The authors have been researching the problem of art therapy for many years. During this period some new practical methods have been developed and patterns have been identified that make art therapy more effective. However, there is still a need to develop individual, culturally oriented scenarios for the application of standard practices, taking into account the cultural background and traditional national culture, which will be readily accepted by patients.

Analysis of recent research and publications. In 1974, according to Keel Holtz's classification, people realized depression. From a medical point of view, de-pression can be divided into «unipolar depression» and «bipolar depression». This paper considers the first category of depression. The topic of FABP and art therapy has been discussed extensively in the recent period by such researchers as Wusheng Zhou, Sekiya Toru, Peixin Meng, Peixin Meng and many others listed in the reference. The above aithirs, in particular Rong Jin, Yinqiao Yang and others, consider the creation of Chinese FABP as inseparable from the deep love for the landscape of nature and the experiences the life and the sketch process bring. The other rhing we can conclude from the recent research is that the Chinese traditional painting art is very close to what Gestalt psychology calls «holism» and the holism theory of human visual perception. Traditional Chinese FABP artists do not care about the secular world, instead devoting themselves to the spiritual world, the painting, the philosophy of art.

Indication of previously unsolved parts of the general problem to which the article is devoted. The essence of art therapy is a non-invasive analysis of mental disorders with simultaneous identification of ways and means to cure them. In this aspect, the impact of FABP therapy on mental health and the corresponding practical application of this artistic technique is still an understudied topic.

Novelty of scientific research. For the first time, the authors apply historical analysis of sources directly together with the results of modern research and practical applications. Much attention is paid to the cultural aspects of patients' perception of art therapy based on traditional genres. The efficiency of the researched method is shown and conclusions concerning the possibility of its application are drawn.

Methodological and general scientific significance of author's developments. The methodological and scientific value of this article lies in the comparative analysis of the reviewed method and other common art therapy methods, as well as in the generalization of the data gathered and knowledge collected up to the present time. 


\section{Presentation of the main material.}

Creating FABP is more attractive and effective in patients than lingvistic influence and communication. Most patients suffering from depression during the adolescent period and middle-age period are those who are socially competent, amiable or meticulous. Sekiya Toru believes that the major cause of depression is the excessive mental stresses brought by the rapid changes of the society. Depression patients are depressed in attitude and expression and are reluctant to talk. As time goes by, patients without treatment develop from unipolar depression to disorders of desire and action. Further, the patients will fail to engage in anything.

As the number of patients voluntarily accepting the painting therapy increases, therapists need to solve the problem of engagement by patients. In this specific case, the author proposes that patients to experience the feeling of "engagement" in tradi-tional Chinese painting. According to the research by the author, the characters of traditional Chinese painting masters are mostly calm and engaged, whether they are Baishi Qi, Tianshou Pan, Weiqu Guo, Changshuo $\mathrm{Wu}$, Zhifo Chen in the modern times or Bai Cui, Song Li, Wei Xu, Da Zhu and Banqiao Zheng in the ancient times of China.Take Weiqu Guo6 as an example, what kind of person is he? According to the artist's wife, Chen junqi, guo weiji is a person with few words. Although he does not care about the housework, but he has set up a "shopping book", the purchase of a detailed calligraphy and painting. He did not compete with others, and in the difficult years of large populations and low wages did not have to hand out subsidies, happy with the painting. He is a elegant Shandong man, the inner rhythm buried in the surface of the calm, expressed in the picture in the elegant. He will be constantly patient to accumulate art history data, also will be immersed in the flower and bird painting of ink incense. His thinking and writing are excellent.

In painting, they engage all energy and pay no attention to the surroundings. Such state is also reflected in their daily life. Not only the art masters, but also the children who learn painting, are generally more engaged in life and study. The aes-thetic characteristics of FABP have developed the artist's focus on calm character, and FABP creation can subtly solve the problem that depression patients can't invest.
The emotion expressed is more complete with FABP creation than in language. Patients with language disorders more urgently need to use painting as a therapy. According to the study on schizencephaly in the twentieth Century, human brain has the feature of functional lateralization. Scientists represented by Roger. W. Sperry, an American Physiological psychologist, suppose that the left hemisphere is in charge of verbal thinking, and the right is in charge of image perception. Based on this mechanism, two cognitive patterns are developed, i.e., the left hemisphere dominance and the right dominance orientation. Logotherapy is effective in curing patients with diseases caused by incorrect cognition or incorrect thinking, but fails to deal with emotional disorders, traumatic experiences and other mental problems. Since the brain deals with sentiments, feelings and emotions with image before verbal, the most direct response of the brain to emotions including depression is image-type and at the same time, the body reacts to such feelings and then the left brain converts it into verbal for storage in the brain by combining of the mind. Since emotions exist in the mind as images, only imago rather than language can directly reach such emotions. Psychologist Ley said, "One cannot unlock the left hemisphere by using the key to the right".

The superiority of FABP art in treating depression. According to our survey, the existing art therapies, such as oil painting, stick drawing, crayon drawing, gouache painting or artistic creation by woven materials, old newspapers, or wet tissues, don't start from the curative effect of art itself applied to painting art therapies of difference theoretical orientations. Freud and Carl Gustav Jung's psychoanalysisoriented art therapy focuses on analyzing the painting content of patients, and in-depth treatment was carried by psychological or psychiatric analysis; as for object relation-oriented art therapy, such as The Artist as Therapist by Arthur Robina, the key is to sort out some chaotic relationship inside the patients by means of painting; phenomenology and existentialism-oriented art therapy focuses on painting work review of patients, so as to obtain some psychological significance from image analysis for follow-up treatment; Gestalt theory-oriented art therapy, relatively lays more emphasis on engagement of patients and Therapist Joseph Zinker follows this philosophy in running his Art Therapy Studio, 
but has to treat patients by analyzing the works of patients; education and development-oriented art therapy is in favor of children and adolescents and the function of painting is similar to an education tool; group therapy-oriented painting art therapy pays attention to the positive significance of painting environment on patients and the information expressed by the painting works; and the last one, humanistic visitor-oriented art therapy is closest to the curative effect of art therapy itself. In Explore Yourself by Expressing yourself, it is illustrated how patients are cured only through art itself, and the psychological balance is restored during the course of artistic creation. By developing the artistic creation potential, patients will find the fun of accepting the "true self" in painting. To set the left hemisphere free, release the stresses, express the self and coordinate the incongruous emotions through painting, the mind and personality can be unified and improved. We should look at the occurrence of art from the perspective of life consciousness, and regard art as an important life activity, which satisfies the inherent needs of life.

The most similar to the characteristics of humanistic psychology is the artistic theory contained in the traditional Chinese painting of flowers and birds. The creation of flower and bird paintings requires the author to be in the breast before creation, to be in the same breath in creation, and to make self-evaluation after creation. Thinking activity is almost full of the whole creative process, which can «trigger» the author's thinking on art and also «trigger» the author's understanding of life from art. After thousands of years of accumulation, Chinese painting and calligraphy theory has formed a profound and powerful theoretical system after continuous self-transcendence in the passage of time. One of them is that the painter must develop his own style. This principle fully embodies the theoretical significance of maintaining individual psychological autonomy in humanistic psychology. The fourth power of psychology after humanistic theory - superindividual psychology believes that the potential purpose of psychological therapy is to seek «consciousness». The essence of Chinese traditional art is «consciousness», which is also the essential characteristic of Chinese traditional flower and bird painting artists. In the use of traditional Chinese art for art therapy, this feature will be able to help patients without pressure to trigger thinking, unconsciously awareness. Through the collision of water, ink and color, the picture forms natural traces, and then turns the unintentional into intentional, accidental into inevitable, and depicts the picture form that one wants. This is how to solve problems by art itself in art therapy.

Art therapy with flower and bird painting as tools is different from ordinary art therapy. It does not only stay at the superficial level of pleasure, but sublimates the simple happiness generated after artistic behavior into spiritual power, and accumulates the quantitative change to the qualitative change, and becomes the huge energy that can eliminate all negative spirits. The creation of flower and bird paintings can let patients immerse themselves in the thoughts of painting, think in the brush and ink, and integrate life into art and realize. The art therapy of flower-and-bird painting gives full play to the value of art therapy.

Chinese art therapy adhering to traditional art culture can affect and cure some personal issues in specific patients. As discussed, using FABP as a tool for depression treatment is not only a feasible art therapy, but also an important research with great significance for the world's depression patients. Painting can release the painters, and some specific FABP can cure patients with lacking of engagement, incomplete expression and depressed mood. It can be treated as a special care for depression patients in China.

The logic thinking of depression patients can get confused and disordered. As the major symptom of depression, the depressed mood medically called the depressed feeling accompanies the patients in their lives, they will lose interest in work and entertainment, and even their normal aesthetic appreciation will be disturbed. The FABP art therapy, using the culture and art created by Chinese people, reshapes the unhealthy image of beauty on the mind of depression patients to enable them to return to their normal lives, so that patients can feel the natural beauty of birds' twitter and fragrance of flowers with joys arising naturally from the inside. It is the curative effect of FABP as an art therapy speculated by the author.

In terms of material selection of Mr. Tan's FABP, the objective things of the aesthetic object are natural things not pure but infused with his unique aesthetic emotion. The ink language of works 
with true feelings, the elegance set off by primitive simplicity, and the charm of combining dynamics into stillness, are the most unique characteristic sentiment of Weiqu Guo as well as his aesthetic perspective and the true him. Both the stillness and dynamic in the paintings containing the vision of harmony between the human beings and the nature pursued by the painting artist, delivers the joyful mood and aesthetic appreciation of the painting artist himself. It is a Chinese style aesthetic temperament carrying the cultural gene of the traditional Chinese art with rich benevolence, righteousness, philanthropy and wisdom of Chinese descendants.

Conclusions. Therapy of depression is studied in this article, namely, the art therapy on the basis of visual image, the existing art therapies on the basis of painting are generalized, their shortcomings are revealed. It has been shown that art therapy with FABP has a positive effect in patients with depression. Particular emphasis is placed on the effectiveness and efficiency of the above technique for Chinese patients with appropriate cultural back- ground. The expediency of using FABP as an art therapy in the treatment of patients with depression is considered in detail. The number of patients with depression is constantly growing and therefore there is a demand for the development of therapy that can be easily accepted by people, which will also be more suitable for long-term treatment, while improving the condition and quality of life of patients. Another necessary condition is the absence of short and long term side effects, FABP painting also satisfies this condition. Depressive disorder also affects the physiological characteristics of the patient. In conclusion it can be said that along with medical treatment, FABP art therapy, which replaces linguistic psychological therapy, is the best way to cure depression.

Possible further use of the results. The results obtained as a result of this study can be used for a deeper study of the topic of application of traditional art techniques and genres by other authors, as well as for the development of new more effective therapeutic and pedagogical practices.

\section{Цитовані праці}

Chuanxi, Chen, Gu, Pingbian. Chen Zhifo. Shijiazhuang: Hebei Education Press, 2002: 122. Print.

Dazhen, Shao. «Passion in Free Expression-Flower-and-Bird Painting of Zilin Zhao». Fine Arts 10 (2013): 138-143. Print.

Huiyu, Liao. «From the Angle of Life Consciousness to View the Genesis of Fine Arts: Taking the Bird and Flower Painting as an Example». Chinese Art 6 (2070) : 104-105. Print.

Jianfeng, Hu. «Psychological Influence of "Calmness" on Creation of Painting and Bird Painting». Art Research 2 (2006): 56-57. Print.

Jie, Tang. «Gorgeous aestheticism with virtual and real». Art Observation 6 (2018): 94-95. Print.

Juting, Liu. «On Linear Spatial Intention of Meticulous Flower-and-Bird Painting». Decoration 10 (2006): 144. Print.

Lu, Yuan. «A Brief Analysis of the Composition Characteristics of Badashanren's Flower and Bird Paintings». Research on Art Education 16 (2018): 13. Print.

Ming, Du. «Exploration of the Relationship between False and Real in Fine Brush-work Flower-and-Bird Paintings». Research on Art Education 22 (2017): 22. Print.

Ming, Ong. «The Difference between Chinese Flower and Bird Painting and Western StillLife Painting from the Perspective of Creative Concept». 35 (2018): 216-219. Print.

Peixin, Meng. Intervention of Painting Art Evaluation and Art Therapy in Patients with Schizophrenia. Beijing: Graduate School of Beijing Normal University, 2004. Print.

Peixin, Meng. Art Therapy-Communication beyond Language. Beijing: Chemical Industry Press. 2009: 1-12. Print.

Ran, Zhang. «On Wei Xu's. Flower and Bird Paintings from the Perspective of Ges-talt Psychology». Popular Literature and Art 11 (2018): 92. Print.

Robins, A. «Object Relations and Art Therapy». Approaches to Art Therap y: Theory And Technique. Aut. J. A. Rubin. 2nd Ed. Philadelphia: Brunner-Routledge, 2001: 54-65. Print.

Rong, Jing. «Visual Psychological Factors in Tianshou Pan 's Landscape Flower and Bird Paintings». Grand View of Art 7 (2018): 58-59. Print.

Sheikh, A. A., J. T, Shaffer. The potential of fantasy and imagination. New York: Brandon House, 1979. Print.

Sekiya, Toru. Depression. Translated by Chunhui Zhao. Changchun: Jilin Science and Technology Press. 2011. Print. 
Siyou, Zhao. «On Artistic Characteristics of Flower and Bird Painting by Zhifo Chen». Decoration 9 (2005): 61-62. Print.

Wenhui, Yang. «Mountains Containing Jade. Emptiness Embracing Everything-On Painting Art of Mr. Baoquan Tan». Art Research 3 (2008): 116-117. Print.

Wusheng, Zhou. «The Doctrine of the Mean of Flowers and Birds in the Yuan Dynasty: A Case Study of Zhao Meng and Other Important Painters». Art Research 16 (2017): 70-71. Print.

Xilin, Liu. «Style and Man-On Weiqu Guo’s Style». Art Research 4 (1992): 10-12. Print.

Yinqiao, Yang. «On Wei Xu's Artistic Achievement of Freehand Brushwork». Art Research 17 (2018): 22-24. Print.

Zhongxin, Ai. «Landscape Flower-and-Bird Painting and Aesthetic Education-Essay on Calligraphy Exhibition of Tianshou Pan». Art Research 3 (1980): 1-6. Print.

\section{References}

Chuanxi, Chen, Gu, Pingbian. Chen Zhifo. Shijiazhuang: Hebei Education Press, 2002: 122. Print.

Dazhen, Shao. «Passion in Free Expression-Flower-and-Bird Painting of Zilin Zhao». Fine Arts 10 (2013): 138-143. Print.

Huiyu, Liao. «From the Angle of Life Consciousness to View the Genesis of Fine Arts: Taking the Bird and Flower Painting as an Example». Chinese Art 6 (2070) : 104-105. Print.

Jianfeng, Hu. «Psychological Influence of "Calmness" on Creation of Painting and Bird Painting». Art Research 2 (2006): 56-57. Print.

Jie, Tang. «Gorgeous aestheticism with virtual and real». Art Observation 6 (2018): 94-95. Print.

Juting, Liu. «On Linear Spatial Intention of Meticulous Flower-and-Bird Painting». Decoration 10 (2006): 144. Print.

Lu, Yuan. «A Brief Analysis of the Composition Characteristics of Badashanren's Flower and Bird Paintings». Research on Art Education 16 (2018): 13. Print.

Ming, Du. «Exploration of the Relationship between False and Real in Fine Brush-work Flower-and-Bird Paintings». Research on Art Education 22 (2017): 22. Print.

Ming, Ong. «The Difference between Chinese Flower and Bird Painting and Western StillLife Painting from the Perspective of Creative Concept». 35 (2018): 216-219. Print.

Peixin, Meng. Intervention of Painting Art Evaluation and Art Therapy in Patients with Schizophrenia. Beijing: Graduate School of Beijing Normal University, 2004. Print.

Peixin, Meng. Art Therapy-Communication beyond Language. Beijing: Chemical Industry Press, 2009: 1-12. Print.

Ran, Zhang. «On Wei Xu's. Flower and Bird Paintings from the Perspective of Ges-talt Psychology». Popular Literature and Art 11 (2018): 92. Print.

Robins, A. «Object Relations and Art Therapy». Approaches to Art Therap y: Theory And Technique. Aut. J. A. Rubin. 2nd Ed. Philadelphia: Brunner-Routledge, 2001: 54-65. Print.

Rong, Jing. «Visual Psychological Factors in Tianshou Pan 's Landscape Flower and Bird Paintings». Grand View of Art 7 (2018): 58-59. Print.

Sheikh, A. A., J. T, Shaffer. The potential of fantasy and imagination. New York: Brandon House, 1979.

Sekiya, Toru. Depression. Translated by Chunhui Zhao. Changchun: Jilin Science and Technology Press, 2011. Print.

Siyou, Zhao. «On Artistic Characteristics of Flower and Bird Painting by Zhifo Chen». Decoration 9 (2005): 61-62. Print.

Wenhui, Yang. «Mountains Containing Jade. Emptiness Embracing Everything-On Painting Art of Mr. Baoquan Tan». Art Research 3 (2008): 116-117. Print.

Wusheng, Zhou. «The Doctrine of the Mean of Flowers and Birds in the Yuan Dynasty: A Case Study of Zhao Meng and Other Important Painters». Art Research 16 (2017): 70-71. Print.

Xilin, Liu. «Style and Man-On Weiqu Guo's Style». Art Research 4 (1992): 10-12. Print.

Yinqiao, Yang. «On Wei Xu's Artistic Achievement of Freehand Brushwork». Art Research 17 (2018): 22-24. Print.

Zhongxin, Ai. «Landscape Flower-and-Bird Painting and Aesthetic Education-Essay on Calligraphy Exhibition of Tianshou Pan». Art Research 3 (1980): 1-6. Print.

Подано до редакції 16.12.2020

Рецензенти:

Стасенко В. В. - кандидат мистецтвознавства, професор;

Ковальчук О. В. - кандидат мистецтвознавства, доцент. 